\title{
Renaut Corpuscles or Peripheral Nerve Infarcts? A Historical Overview
}

\author{
Mohamed Kazamel, Christopher J. Boes
}

\begin{abstract}
Renaut corpuscles are cylindrical hyaline structures that arise from the peripheral nerve perineurium and project into the endoneurium. Despite their earlier accurate description in the French and German literature, Kernohan and Woltman (1938) reported very similar structures as "nerve infarcts" in a case series of vasculitic neuropathy. Krücke (1955) deserves credit for discovering this error and further explaining how peripheral nerves react differently (from brain parenchyma) to ischemia. We tried to elucidate the reason why Kernohan and Woltman, and others, made this scientific error by describing the historical evolution of our understanding of the structure and function of Renaut corpuscles.
\end{abstract}

RÉSUMÉ: Corpuscules de Renaut ou « infarctus des nerfs périphériques » ? Les corpuscules de Renaut sont des structures hyalines de forme cylindrique issues du nerf périphérique de la périnèvre et se projetant dans l'endonèvre. En dépit de leur description ancienne et précise dans la littérature scientifique française et allemande, Kernohan et Woltman (1938), se référant à des cas de neuropathie vasculitique, ont caractérisé des structures très similaires comme des « infarctus de nerfs ». Le mérite d'avoir découvert cette erreur scientifique revient à Krücke (1955). Ce dernier a en outre expliqué de quelle façon les nerfs périphériques, à partir du parenchyme cérébral, réagissent différemment dans le cas d'une ischémie. En décrivant l'évolution historique de notre compréhension des structures et fonctions des corpuscules de Renaut, nous avons ainsi tenté de comprendre pourquoi Kernohan, Woltman et d'autres ont commis cette erreur scientifique.

Keywords: History of neuropathology, Joseph-Louis Renaut, Renaut corpuscles, Renaut bodies, Wilhelm Krücke doi:10.1017/cjn.2016.406

Can J Neurol Sci. 2017; 44: 184-189

\section{INTRODUCTION}

Renaut corpuscles (or bodies) are cylindrical longitudinal hyaline-appearing structures that are found in the subperineurial space of human and animal peripheral nerves (Figure 1). ${ }^{1-5}$ Histologically, they are composed of fibroblasts and perineurial cells immersed in an extracellular matrix of randomly oriented collagen fibers and elastin precursors, but not axons or Schwann cells. ${ }^{6}$ Found in $2 \%$ of superficial fibular and $7.5 \%$ of sural nerves, ${ }^{7,8}$ they were first described in horses and donkeys by Joseph Renaut in 1881, who called them "système hyalin" or the hyaline system. ${ }^{2}$ Schultze and Pick attached Renaut's name to the structures. ${ }^{9,10}$ Renaut speculated that these structures might have a supportive mechanical cushioning action, because he found them mainly in long nerve trunks passing through large muscle groups. ${ }^{1}$ Further human and animal studies supported this notion by finding them at sites of median, ulnar, lateral femoral cutaneous and suprascapular nerve entrapments. ${ }^{11-13}$

In 1938 James W. Kernohan, a Mayo Clinic neuropathologist, and Henry W. Woltman, a Mayo Clinic neurologist, described the autopsies of five patients with "periarteritis" (polyarteritis) nodosa, focusing on the neuropathological findings. They described structures similar to Renaut corpuscles as "peripheral nerve infarcts" (Figure 2). ${ }^{14}$ Here we try to elucidate the reason why they, and others, made such a scientific error by describing the historical evolution of our understanding of the structure and function of Renaut corpuscles.

\section{METHOD}

We reviewed the original articles that described the structure of Renaut corpuscles in animals and man, including those published by Joseph Renaut and Eikichi Okada. We also examined the paper in question by Woltman and Kernohan and the subsequent relevant publications of Wilhelm Krücke and Peter J. Dyck. The Renaut publications were translated from French, and the Okada and Krücke publications were translated from German to English through the Mayo Clinic Unit of Language Services.

\section{RESULTS}

Joseph-Louis Renaut (Figure 3) finished his medical studies in College de France, Paris, in 1869. He trained in histology under Louis Antoine Ranvier before completing his medical thesis on erysipelas in 1874 . He then became the director of the pathological anatomy laboratories at the Charité Hospital in Paris. In 1877, he accepted chairmanship of the general anatomy and histology department at the new Medical Faculty of Lyon. Aside from Renaut corpuscles, his contributions in histology and pathology were diverse. They included the description of the

\footnotetext{
From the Department of Neurology, Mayo Clinic, Rochester MN, 55905, USA.

Received April 6, 2016. Final Revisions Submitted August 30, 2016. Date of ACCEPTANCE SEPTEMBER 13, 2016.

Correspondence to: Christopher J. Boes, Department of Neurology, Mayo Clinic, 200 First St SW, Rochester, MN 55905. Email: boes.christopher@mayo.edu
} 

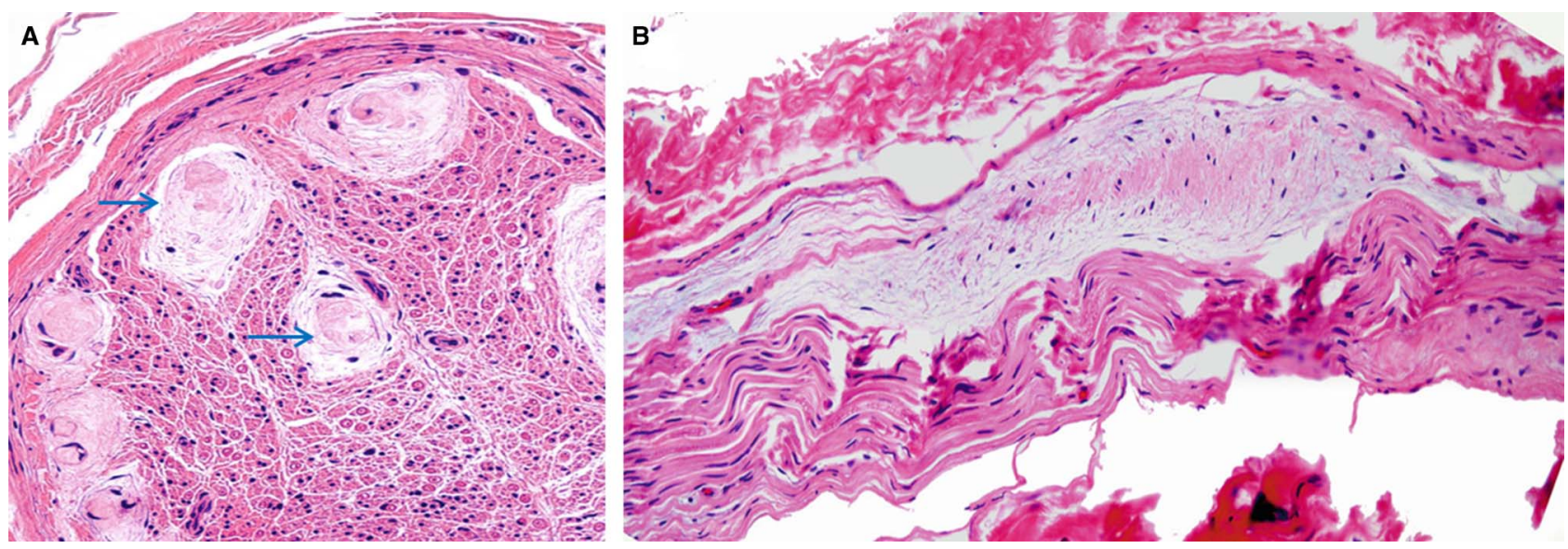

Figure 1: Renaut corpuscles are shown in hematoxylin and eosin cross (arrows, A) and (B) longitudinal sections, 400X, with permission. ${ }^{5}$

fibro-hyaline membrane between the skin keratin and dermis (known as "Renaut's Layer"), secretory functions of the intestinal epithelium and lung alveoli, and syncytial nature of cardiac muscle fibers. ${ }^{15} \mathrm{He}$ also described the myopathological features of chronic denervation following lead toxicity. He hypothesized that the faster development of muscle weakness in lead intoxication, as compared to progressive muscular atrophy, was due to the more severe muscle fiber atrophy and secondary myopathic changes (muscle fiber necrosis) in the former. ${ }^{16}$

In describing this "hyaline system" in the nerves of horse and donkey, Renaut wrote:

In large nerves such as the median and facial trunk, you see at some points that the hyaline system is considerably developed. On one side of the nerve bundle, the connective tissues vegetate and become loaded with gadroon cells. ${ }^{1}$

I have long sought an interpretation and I confess that I can find no other than the following: In adult animals advanced in age such as those sacrificed in the veterinary schools, the nerves constantly produced new interannular hyaline segments that vegetate in the periphery and replace the nerve elements whose evolution is completed. ${ }^{2}$

In his article published in German, Japanese histologist Eikichi Okada (1903) further characterized the structure of Renaut corpuscles in humans. He speculated that their origin was perineurial, relying just on morphological observation:

They lie simply in nerve bundles, mostly and specifically on the inner surface of the perineurial ring, but they are also not rare next to the endoneurial septa within the bundle, quite isolated yet seemingly surrounded by nerve fibers. Nothing like this is detectable in the epineurium. If they lie close to the perineurium, then they partly touch the latter directly with their periphery, partly separated from it by a fine lymph fissure. They did not obtain their space by protruding through the perineurium, but rather at the expense of the nerve fibers, which supposedly are simply displaced or subject to atrophy. ${ }^{17}$
Okada called these structures "Die Zwiebeln", the bulbs:

What is the bulb like in longitudinal sections? With a slight enlargement, detectable between the tight connective tissue outlines of the perineurium and the nerve fibers, also more rarely in the intrafascicular septa, is a long, stretched, clear area that terminates near both poles either by tapering gradually or appearing as if suddenly torn. ${ }^{17}$

However, he was not sure of the function of these "bulbs" and noted that "it has become debatable whether they have any pathological significance or whether they are nothing other than a physiological formation."17

Henry W. Woltman graduated from medical school at the University of Minnesota in 1913. He completed a Ph.D. thesis on the effect of pernicious anemia on the central nervous system in $1917 .{ }^{18} \mathrm{He}$ was recruited by Walter Shelden to join the Mayo Clinic staff in the same year. He was the first Mayo Clinic practicing physician with formal post-graduate training in neurology. ${ }^{19}$ He became the chair of the section of neurology at the Mayo Clinic (1930-1954) ${ }^{20}$ and the president of the American Neurological Association in $1950 .{ }^{21}$ He described the delayed relaxation of the tendon jerk in hypothyroidism (Woltman's sign $)^{22}$ and the false localizing sign of tentorial herniation with James Kernohan. $^{23}$

James W. Kernohan finished medical school at Queen's University, Belfast, in 1920. He then worked as a clinical pathologist at the Crichton Royal Institute in Dumfries, Scotland (19211922). ${ }^{24} \mathrm{He}$ moved to Mayo Clinic for fellowship training in anatomy and pathology (1922-1924). Thereafter, he joined the pathology department staff in the same institution (1924-1961). ${ }^{25}$ In 1949 he published a pathological classification of glial brain tumors, categorizing them into four grades based on the degree of anaplasia. ${ }^{26}$ This classification is now universally recognized as the foundation of the current World Health Organization (WHO) classification system for brain tumors. ${ }^{27}$

In 1938, Woltman and Kernohan described the neuropathological findings in the autopsies of five cases of periarteritis (polyarteritis) nodosa. Three cases had involvement of the peripheral nerves, one of the brain, and one of the eye choroid layer. 


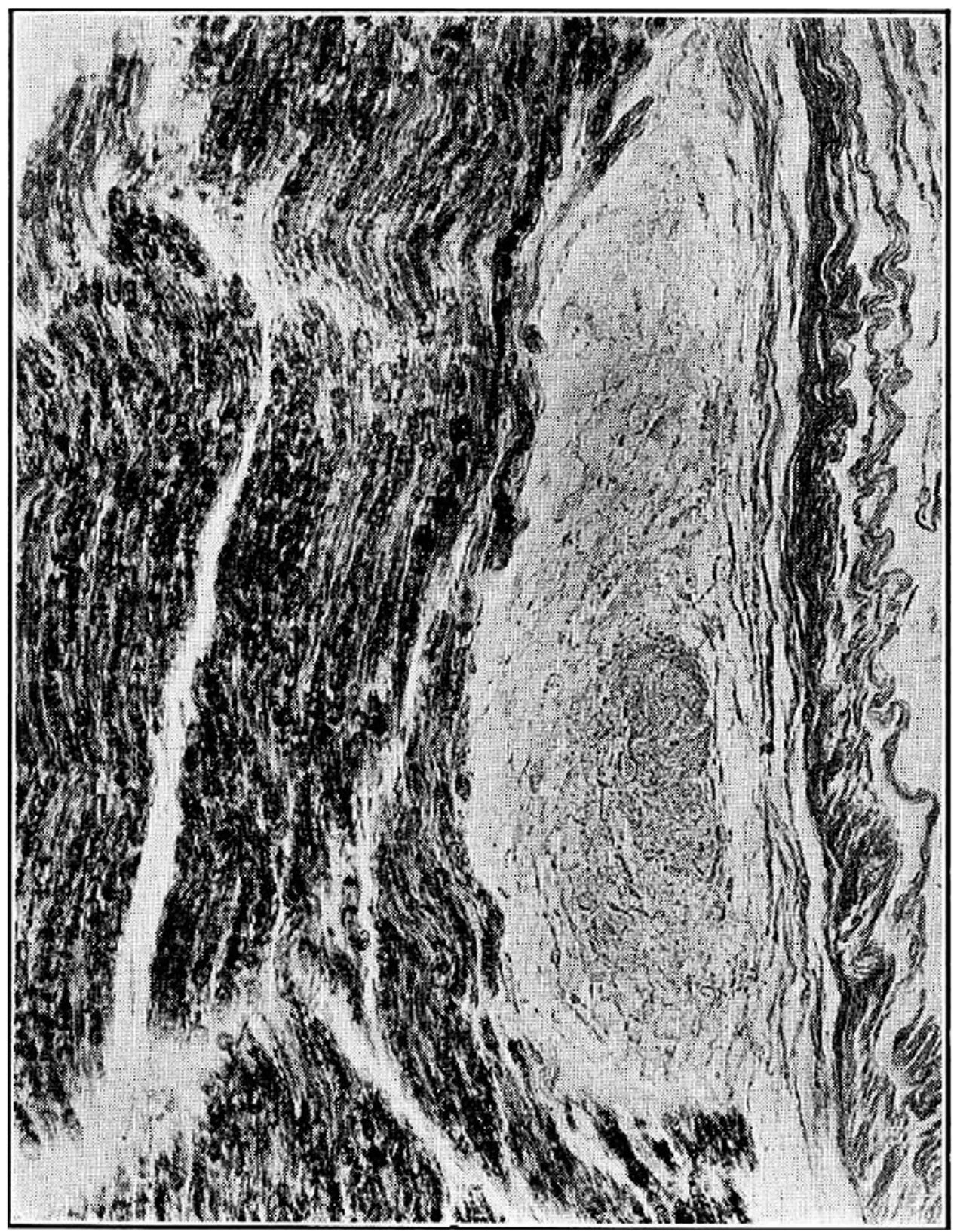

Figure 2: A figure from the 1938 Kernohan and Woltman article, showing a longitudinal section in a sciatic nerve and describing a structure that is very similar to a Renaut corpuscle as a "peripheral nerve infarct." 14

They provided an accurate description of the primary site of pathology in the blood vessel wall:

We have used throughout the reports of the cases in this study the term 'periarteritis nodosa' because it is the one most commonly in use, but it is in reality a misnomer. The primary lesion in the arteries is hyaline-like necrosis of a portion of the media and the internal elastic lamina. This is followed by extension of the inflammatory process to the adventitia and by periarteritis. ${ }^{14}$
In two cases they described "peripheral nerve infarcts" in the brachial plexus and sciatic nerve:

We believe that the lesions in the nerves are solely the result of inadequate blood supply. We saw many infarcts in the nerves which we examined; in some nerve bundles there was only one infarct (figure 2) . . . We feel assured that the infarcts were the cause of the degeneration and of the clinical manifestations of pain and weakness from which most of these patients suffer. ${ }^{14}$ 


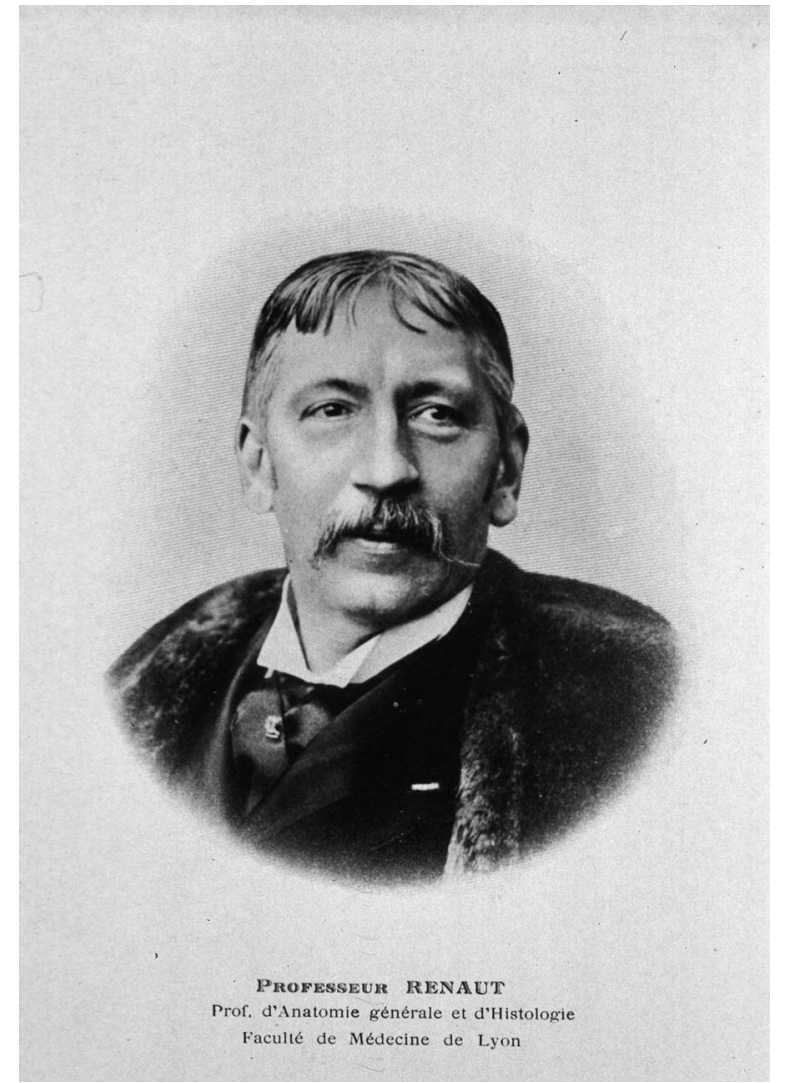

Figure 3: Joseph-Louis Renaut (1844-1917). Courtesy of the U.S. National Library of Medicine.

Wilhelm Krücke graduated from University of Frankfurt in 1934. He worked as a research assistant to Hallervorden and Spatz at the Kaiser Wilhelm institute in Berlin (1939-1944). He managed to save the neuropathology tissue archives after the end of World War II by transferring them to Dillenburg, the new location of the institute. Krïcke published several articles on the pathology of toxic and inflammatory neuropathies. ${ }^{28}$ In a book chapter published in 1955, he indicated that what Woltman and Kernohan earlier described as "peripheral nerve infarcts" could actually have been Renaut corpuscles:

The most frequently described parenchymal disintegration of the peripheral nerves is the Wallerian degeneration. Kernohan and Woltman were the only ones to report localized infarcts in the nerve. However, and according to the attached figure, it is unclear whether or not they were Renaut bodies. In all the other cases reported up till now, no full necrosis was detectable in the nerves. In contrast, a few individual nerve fiber bundles showed near total demyelination and Wallerian degeneration. ${ }^{29}$

In 1972 Dyck, Conn, and Okazaki reported the results of extensive post-mortem pathologic studies on the nerves of a patient with rheumatoid arthritis and peripheral neuropathy. More than 15,000 sections were obtained on different limb nerves with specific staining of both myelinated nerve fibers and vasa nervosa alternatively. They aimed to better understand the three dimensional relationship between the locations of nerve fiber degeneration and the sites of occlusive vasculitic lesions. They supported Krücke's earlier views that liquefactive necrosis and infarction do not happen in the same way in the peripheral and central nervous systems. They agreed with him that what Woltman and Kernohan earlier reported were in fact Renaut corpuscles:

Krïcke, in an extensive review of the subject, pointed out that Kernohan and Woltman were the only ones who have described a localized infarct in the nerve bundle. He correctly, in our opinion, expresses the view that the illustrated structures identified as 'infarcts' are in fact not infarcts but probably are Renaut corpuscles. Such structures have received little attention in the English-language literature but have been discussed extensively in the German medical literature. There have been reports of 'infarcts' in nerve since Krücke's review, but these would not be acceptable because the illustrations were either of Renaut corpuscles or of patchy regions of [fiber degeneration]. Krücke has said that 'softening,' as seen in the brain (a circumscribed necrosis of all cellular elements leading to liquefaction with a border zone of macrophages), has not been convincingly demonstrated in peripheral nerve. We concur with this statement. $^{30}$

\section{Discussion}

Renaut corpuscles are important benign structures that must be recognized by the neuropathologist in order to avoid assigning them unwarranted significance. ${ }^{4}$ Despite the early accurate description of Renaut corpuscles in 1881, they were occasionally mislabeled as "peripheral nerve infarcts" or amyloid deposits until the 1970s. We have tried to discern the reasons why a few prominent names in the field of neuropathology did so over the years.

The uncertainty about the histological origin and pathophysiological significance of Renaut corpuscles contributed to this problem. Okada, after describing them in humans and reviewing the opinions of others, was still unsure of their physiological significance. He noted a difference of opinion in the literature. On the one hand, Renaut thought that they were physiological structures that might have a supportive function, ${ }^{1,2}$ and Pick believed they had no pathological significance. ${ }^{10}$ On the other hand, Ott favored the view that they were pathologic, based on the fact that they were irregular, inconsistent, and focal. ${ }^{17,31}$

More recent studies have concluded that there can be a pathologic relationship between Renaut corpuscles and nerve compression. ${ }^{4,8,11,32}$ These conclusions were based mainly on observations that they were (1) common at entrapment sites, (2) abundant in aging animal nerves and absent in fetal nerves, and (3) contained fibroblasts and elastic fibers. Experimental production of Renaut corpuscles by applying chronic compression demonstrated an evolution from foci of endoneurial edema and gradual accumulation of fibroblasts and fibrillary substance, until a mature Renaut corpuscle was formed. ${ }^{33}$ However, in another experimental model of axonal transection without regeneration, one year after transection the cut nerve fascicles were filled with fibroblasts and fibrillary structures very similar to those of Renaut corpuscles. ${ }^{34}$ Moreover, they are still found in healthy nerves that 
are not commonly liable to compression like the sural and superficial fibular nerves. $^{4,8}$

Relying solely on morphological observations, Okada argued for the perineurial origin Renaut corpuscles. However, he indicated that he was still open to debate with authors like Schultze, ${ }^{35}$ Oppenheim, ${ }^{36}$ Rosenheim, ${ }^{37}$ and Nonne, ${ }^{38}$ who thought that these structures were merely sclerosed obliterated blood vessels, and with others like Rakmaninoff, ${ }^{39}$ Blocq, and Marinesco, ${ }^{40}$ who considered them decaying products of neural tissue. Recent immunohistochemical studies support Okada's view of their perineurial origin. 6,8

This was not the only incident where Renaut corpuscles were mistakenly called "peripheral nerve infarcts." Such misinterpretation was also seen in an earlier publication by Woltman. ${ }^{41}$ Moreover, nerve infarct was not the only incorrect label Renaut corpuscles were given. In a case of recurrent demyelinating neuropathy, they were called "amyloid deposits." 42 Dyck et al. indicated that even after Krücke's review was published, such mislabeling continued to be seen in the English literature. We believe that they were referring to a 1968 article by Raff et al. describing the clinical and pathologic changes in cases of diabetic mononeuropathy multiplex. ${ }^{43}$ Asbury, the last author on that paper, acknowledged this error in 1973. ${ }^{4}$ He called Renaut corpuscles "forgotten endoneurial structures" that were not discussed in the English literature for 90 years until Dyck and Lambert described them in hypothyroid neuropathy cases. ${ }^{3}$ To our knowledge the majority of the articles that further described the structure and discussed the function of Renaut corpuscles in this 90-year interval were published in German, ${ }^{9,10,17,31,35-38}$ and less often in French. ${ }^{39,40}$

Dyck et al. attributed the absence of localized infarcts in the peripheral nervous system to the fact that epineurial arterioles are not end arteries, thus nerve ischemia often leads to a lesser degree of tissue anoxia. They also thought that the peripheral nerve tissues (Schwann cells, perineurial cells, and connective tissue) are less susceptible to anoxia than the metabolically more active neuron cell bodies that are located in or close to the spinal cord. ${ }^{30}$ In 1984 , Nukada and Dyck demonstrated the effect of injecting the arteries supplying a rat ischiatic nerve with gradually increasing numbers of polystyrene microspheres. This experiment provided strong evidence that peripheral nerve ischemia leads to areas of Wallerian fascicular degeneration rather than circumscribed infarcts. ${ }^{44}$

We conclude that despite their earlier accurate description in the French and German medical literature, Renaut corpuscles were given a false pathologic interpretation by Kernohan, Woltman, and others. Krücke and Dyck deserve credit for discovering this error and further explaining how peripheral nerves react differently, from brain parenchyma, to ischemia due to vasculitis. The mislabeling of Renaut corpuscles as "peripheral nerve infarcts" highlights the scientific gap that arose during the transition of the preferred language of medical publications from German to English in the first half of the $20^{\text {th }}$ century.

\section{ACKNOWLEDGEMENTS}

We thank Dr. Peter J. Dyck for providing us with some of the main historical references that were used in this work.

Part of this work was presented in the International Society for the History of the Neurosciences (ISHN) $20^{\text {th }}$ annual meeting, Washington, D.C., USA, June 1-6 ${ }^{\text {th }}, 2015$.

\section{Disclosures}

Mohamed Kazamel and Christopher Boes do not have anything to disclose.

\section{STATEMENT OF AUTHORSHIP}

Mohamed Kazamel and Christopher Boes both participated in the design of the study, collection of data, and preparation of the manuscript.

\section{REFERENCES}

1. Renaut J. Système hyalin de soutènement des centres nerveux et de quelques organes des sens. Arch Physiol (Paris). 1881; 8:846-59.

2. Renaut J. Recherches sur quelques points particuliers de l'histologie des nerfs. I. La gaine lamelleuse et le système hyalin intervaginal. Arch Physiol Norm Pathol. 1881;8:180-90.

3. Dyck PJ, Lambert EH. Polyneuropathy associated with hypothyroidism. J Neuropathol Exp Neurol. 1970;29:631-58.

4. Asbury AK. Renaut bodies. A forgotten endoneurial structure. J Neuropathol Exp Neurol. 1973;32:334-43.

5. Bilbao JM, Schmidt RE. Normal Anatomy of the Peripheral (Sural) Nerve. Biopsy Diagnosis of Peripheral Neuropathy. 2nd ed. New York, Dordrecht, London: Springer; 2015. p. 21-41.

6. Pina-Oviedo S, Khalili K, Del Valle L. Hypoxia inducible factor-1 alpha activation of the JCV promoter: role in the pathogenesis of progressive multifocal leukoencephalopathy. Acta neuropathol. 2009;118(2):235-47.

7. Bergouignan FX, Vital C. Occurrence of Renaut's bodies in a peripheral nerve. Arch Pathol Lab Med. 1984;108(4):330-3.

8. Weis J, Alexianu ME, Heide G, Schroder JM. Renaut bodies contain elastic fiber components. J Neuropathol Exp Neurol. 1993; 52:444-51.

9. Schultze F. Ueber circumscripte Bindegewebs spindeln (Nodules Hyalins Von Renaut) in den peripheren Nerven des Menschen. Virchows Archiv fur pathologische Anatomie. 1892;129.

10. Pick F. Über die Renaut'schen Körperchen (endoneurale Wucherung, Langhans). Zbl Path. 1901;12:212-8.

11. Neary D, Ochoa J, Gilliatt RW. Sub-clinical entrapment neuropathy in man. J Neurol Sci. 1975;24(3):283-98.

12. Jefferson D, Neary D, Eames RA. Renaut body distribution at sites of human peripheral nerve entrapment. J Neurol Sci. 1981;49(1): 19-29.

13. Duncan ID, Schneider RK, Hammang JP. Subclinical entrapment neuropathy of the equine suprascapular nerve. Acta neuropathol. 1987;74(1):53-61.

14. Kernohan JW, Woltman HW. Periarteritis nodosa: a clinicopathologic study with special reference to the nervous system. Arch neurpsych. 1938;39:655-86.

15. Weiner DB. Renaut, Joseph-Louis. Complete Dictionary of Scientific Biography 2008 [cited 2016 01/05]; Available from: http:// www.encyclopedia.com.

16. Renaut J, Debove M. Note sur les lésions des faisceaux primitifs des muscles votontaires dans 'atrophie musculaire progressive et dans la paralysie saturnine. Gaz médicale de Paris. 1876;5:114.

17. Okada E. Ueber Zwiebelartige Gebilde im peripherischen Nerven (Renaut'sche Korperchen) bei einem Fall von Kakke (Beriberi). Tokyo Imperial Univ Coll Med. 1903;6:93-119.

18. Todman D. Henry Woltman (1889-1964): pioneering American neurologist. Journal of medical biography. 2008;16(3):162-6.

19. Corbin KB, Kernohan JW. Henry William Woltman, M.D., 18891964. Neurology. 1965;15:413-4.

20. Mulder DW. Past, present, and future of the Mayo Department of Neurology. Mayo Clin proceed, Mayo Clinic. 1971;46(4):289-91.

21. De Jong R. History of American Neurology. New York: Raven Press; 1981.

22. Chaney WE. Tendon reflexes in Myxoedema: valuable aid in diagnosis. Journal of the American Medical Association. 1924; 82:2013-6. 
23. Kernohan JW, Woltman H.W. Incisura of the crus due to contralateral brain tumour. Archives of Neurology and Psychiatry. 1929;21:274-87.

24. Dahlin DC. James Watson Kernohan: 1896-1981. Surg Neurol. 1984;21(2):107-9.

25. Etienne D, Zurada A, Matusz P, Shoja MM, Tubbs RS, Loukas M. James Watson Kernohan (1896-1981: Frontiers in neuropathology. Clin Anat. 2012;25(4):527-9.

26. Kernohan JW, Mabon RF, Svien HJ, Adson AW. A simplified classification of the gliomas. Proceedings of The Staff Meetings of The Mayo Clinic. 1949;24:71-5.

27. Haines DE, Lancon JA, Zubkov AY. James Watson Kernohan (1896-1981). J Neurol. 2005;252:1558-9.

28. Schlote W. In memoriam Wilhelm Krücke. Acta neuropathol. 1989;77:557-60.

29. Krücke W. Erkrankungen der peripheren Nerven. In: Lubarsch O, Henke F, Rossle R, editors. Handbuch der speziellen pathologischen Anatomie und Histologie B: Erkrankungen des peripheren Nervensystems. Berlin: Springer-Verlag; 1955, p. 105-17.

30. Dyck PJ, Conn DL, Okazaki H. Necrotizing angiopathic neuropathy. Three-dimensional morphology of fiber degeneration related to sites of occluded vessels. Mayo Clin proceed Mayo Clinic. 1972;47(7):461-75.

31. Ott N. Über peri- und endoneurale Wucherungen in den Nervenstämmen einiger Thierspecies. Virchow's Archives. 1894;136:69.

32. Grover-Johnson N, Spencer PS. Peripheral nerve abnormalities in aging rats. J Neuropathol Exp Neurol. 1981;40(2):155-65.

33. Ortman JA, Sahenk Z, Mendell JR. The experimental production of Renaut bodies. J Neurol Sci. 1983;62(1-3):233-41.
34. Roytta M, Salonen V. Long-term endoneurial changes after nerve transection. Acta neuropathol. 1988;76(1):35-45.

35. Schultze F. Über den mit Hypertrophie verbundenen progressiven Muskelschwund. Schmidt's Jahrbücher. 1886;211:102.

36. Oppenheim H, Siemerling E. Beiträge zur Pathologie der Tabes dorsalis und der peripherischen Nervenerkrankung. Archiv für Psychiatrie u Nervenkrankheiten. 1887;18:98.

37. Rosenheim T. Zur Kenntniss der acuten infectiösen multiplen Neuritis. Archiv für Psychiatrie u Nervenkrankheiten. 1887; 18:782.

38. Nonne M. Klinisches und pathologisch-anatomisches zur Lehre von der combinirten Schulterarmlähmung und der partiellen Entartungsreaction. Deutsches Archiv für klin Medicin. 1887;40:62.

39. Rakmaninoff $\mathbf{J}$. Contribution à la neurite peripherique. Revue de médecine. 1892:334.

40. Blocq PO, Marinesco G. Sur un système tubulaire spécial des nerfs. Gazette médicale de Paris. 1892;63:361.

41. Woltman HW, Wilder RM. Diabetes mellitus: pathologic changes in the spinal cord and peripheral nerves. Arch Intern Med. 1929;44:576-603. [Figs. 1,2].

42. Prineas JW, McLeod JG, Wolfenden WH. Endoneurial deposits of amyloid-like fibrils in a recurrent demyelinating neuropathy. An electron microscope study. J Neuropathol Exp Neurol. 1971; 30(4):583-92. [Figs 1,2].

43. Raff MC, Sangalang V, Asbury AK. Ischemic mononeuropathy multiplex associated with diabetes mellitus. Arch Neurol. 1968; 18(5):487-99. [Fig. 5].

44. Nukada H, Dyck PJ. Microsphere embolization of nerve capillaries and fiber degeneration. Am J Pathol. 1984;115(2):275-87. 